specialized in the works of early voyagers to the southern hemisphere in which there is any mention of birds, and his collection includes a copy of that very rare book published in 1701 by William de Vlaming, a "Journal of a Voyage to the Unexplored Southland .. . in 1696 and 1697". Of books on Australian birds, there is a complete set of all the editions of Lewin's "Birds of New Holland", starting with the first, published in 1808, of which there are only six known copies. Gould's great folio work is of special interest, since it includes the two parts published before the author went to Australia and afterwards withdrawn and replaced, after his return.

SnNce Mr. Mathews takes a great interest in nomenclature, his library naturally includes many rare and little-known general works. Among these may be mentioned Vroeg's "Catalogue" (1764), and Boddaert's "Table des Planches Enluminées" (1783), the former not included in the British Museum's (Natural History) library, and the latter only represented by a photostat copy and a reprint. Other rare and interesting books include Rafinesque's works (1814-22), Berthold's edition of "Natürliche Familien des Thierreich" by Latreille (1827), and Moehring's "Avium Genera" (1752). There are complete sets of certain periodicals such as the Isis, and more particularly of local journals published in Australia, including the first volume of the Queensland Philosophical Society, which is said to be unique. After having completed his "Birds of Australia", $\mathrm{Mr}$. Mathews brought out an additional volume of bibliography, and, with a few exceptions, all the books mentioned therein are in his possession. The acquisition of this library should now enable students in Australia to study ornithology independently of the libraries in Europe and elsewhere.

\section{Nutritional and Allied Aspects of Milk}

IT has already been announced that the new Division for the Social and International Relations of Science of the British Association is arranging a meeting for the discussion of this subject to be held on March 28 at the University of Reading. Representatives of a number of interested public bodies and institutions will be present. The meeting will be divided into two sessions, lasting from 2.15 to 4.15 and from 5.15 to 7.0 , with an interval for tea. At the first session the chair will be taken by Sir Richard Gregory, chairman of the Division. Dr. Harriette Chick will open the discussion, dealing with deficiencies in present-day diet, the total amount of milk needed, etc., Prof. J. C. Drummond will discuss health aspects, and Dr. A. W. Scott will speak on the implications of compulsory pasteurization. At the second session, Sir Daniel Hall will be in the chair. Mr. J. MacKintosh will discuss agricultural aspects of milk production, with special reference to increase of production, and Mr. J. Cripps will speak on the distribution, cost and the economic and social implications allied with the subject. The meeting will be preceded, in the morning, by a visit to the National Institute for Research in Dairying at Shinfield, near Reading. Arrangements will be made for lunch, tea and dinner to be served in the University so far as accommodation permits, and accommodation for the night preceding the meeting may be arranged if a sufficient number desire it. Admission will be free, by ticket. A limited number of tickets will be obtainable from the Secretary, British Association, Burlington House, London, W.I.

\section{The Institute of Chemistry}

Ax the sixty-first annual general meeting of the Institute of Chemistry held on March 1, Sir Robert Pickard, the retiring president, directed attention to the fact that the membership now consists of more than 7,200 qualified chemists. The Council is endeavouring to obtain the consent of the fellows and associates to a petition for a supplemental charter embodying a scheme for the registration of those chemists whose qualifications are the same as those required for admission to the Institute, but who do not wish to become fully associated with its work. It is, in Sir Robert's view, a scheme proposed in the best interests of the Institute, of the profession as a whole, and of the State. Sir Robert referred to the possible utilization of the services of chemists in any national emergency. The position of the country, so far as the supply of chemists and the condition of the chemical industries are concerned, is very different from that of twentyfive years ago ; but war usually brings unexpected demands, and chemists will be glad to know that an organized effort is being made which will direct their skill and willingness to serve the country into the most advantageous channels. The Institute is fortunate that, in times like the present, less than $\mathbf{l} \cdot \mathbf{2}$ per cent of its members are known to be without employment, and only a small proportion of those has been unemployed for any long period. Sir Robert directed attention to the third annual report of the Chemical Council, recently published. This body, on which the Institute is represented, has under consideration a scheme the object of which is to distribute the burden of the cost of publications of the Chemical Society and the Society of Chemical Industry more equitably over the membership of all three chartered chemical bodies. The Meldola Medal, the gift of the Society of Maccabrans, has been awarded to Dr. William Charles Price. The following officers for 1939-40 have been elected: President, Mr. W. A. S. Calder ; Vice-Presidents, Dr. H. V. A. Briscoe, Dr. F. H. Carr, Dr. T. P. Hilditch, Mr. G. Roche Lynch, Dr. C. Ainsworth Mitchell, and Sir Robert Pickard; Hon. Treasurer, Mr. B. F. Howard.

\section{Society of Public Analysts and Other Analytical Chemists}

AT the annual general meeting of the Society of Public Analysts and Other Analytical Chemists held on March 3, the following officers were elected for the year 1939-40: President, Prof. W. H. Roberts; Vice-Presidents, E. B. Anderson, J. R. Nicholls, W. H. Simmons, T. P. Hilditch (chairman, North of England Section), T. Cockburn (chairman, Scottish Section); Hon. Treasurer, E. B. Hughes; Hon. Secretary, Lewis Eynon. Following the annual 